\title{
The Challenges of Water Pollution: Enforcement of Water Pollution Control
}

\author{
I Made Arya Utama, I Nengah Suharta \\ Faculty of Law, Udayana University, Indonesia. E-mail prof_imautama@yahoo.co.id
}

\begin{tabular}{l} 
ARTICLE INFO \\
\hline Keywords: \\
Legal Enforcement; \\
Pollution; Prevention; \\
Sanction; Water \\
How to cite: \\
Utama, I.M.A., and \\
Suharta, I.N. (2018). The \\
Challenges of Water \\
Pollution: Enforcement of \\
Water Pollution Control. \\
Hasanuddin Law Review, \\
4(1): 81-87 \\
DOI: \\
10.20956/halrev.v4i1.1414
\end{tabular}

\begin{abstract}
Water demand continues to increase, while its availability was increasingly limited due to pollution. Therefore, the issue of legal sanction in the management of water resources was interesting to be examined because of the void of norm related to the sanction of administrative, civil and criminal sanction in Article 87-120 of Act Number 32 of 2009. So, this research was qualified into normative legal research with legal material from result of library research. The type of administrative legal sanctions were more effectively applied to protect water resources from pollution. Administrative Legal Sanction was not implemented through the judges, more easily and quickly implemented in providing protection against water resources, compared with sanctions of Criminal Law and Civil Law.
\end{abstract}

\section{Introduction}

Utilization of water resources for various community needs and development is increase continuous. On the other hand, the availability of water resources is increasing limited as be caused the environmental degradation by pollution. In this case, it is necessary to conserve water resources for balance in fulfill short-term and long-term needs (sustainable of water management). In this matter, one of the instruments is done through the application of legal sanctions as stipulated in Articles 76-82 (administrative sanctions), Articles 87-92 (Civil Sanction), Articles 97-120 (Criminal sanctions) on Act number 32 of 2009. However, normatively there is a void of norms associated with prioritization in the application of these three sanctions in the prevention of various violations of legal products that occur in the realization of the quantity and quality of water in a sustainable manner. 


\section{Method}

This research is a normative legal research. The normative legal research that goes from the void of norms through conceptual approach and a statutory approach. Meanwhile, this research was based on the results of library research, both for primary legal materials and secondary legal materials to be processed, described, and analyzed qualitatively to get the conclusions on the issues studied.

\section{Authority to Protect Water Resources from Pollution}

Normatively, water resources are part of the environment. This can be seen in Article 1 point 1 of Act number 32 of 2009 on Environmental Protection and Management (UUPLH) which defines the concept of the environment as "the unity of space with all things, power, state and living things, including human beings and behaviors, affecting nature itself, the survival of life, and human welfare and other living beings". Water resources as a part of natural resources shall be maintained for the sustainability of supporting human life and development. The relationship between the principles of environmentally sound development with the concept of sustainable development above by Daud Silalahi is likened to two sides of the same coin, so it is interrelated. ${ }^{1}$ Therefore it is not excessive when Hardjasoemantri ${ }^{2}$ states the principle of environmentally sound development as a keyword in order to carry out development at this time and in the future.

In managing water resources through the Deep ecology approach requires a new ethics that is not human-centered, but instead focuses on the whole life with the effort to overcome environmental problems. ${ }^{3}$ One of the instruments developed to make it happen through the instruments of Environmental Law as a whole of the rules governing the behavior of people about what should be done to the environment, the implementation of the regulation can be imposed through a sanction by the authorities. ${ }^{4}$

\section{Potential of Pollution to Water Resources in Bali}

Article 1 point 14 of Act number 32 of 2009 stated the concept of environmental pollution as ".... the entry or inclusion of living beings, substances, energies, and/or other components into the environment by human activities, thus exceeding the quality standard the prescribed environment". The indicator of suspected water pollution can be known and observed visually as well as laboratory test results related to changes in potential hydrogen $(\mathrm{pH})$ or concentration of a substance as measured by the criteria of the Environmental Quality Standard.

Potential contamination of water resources occurs also in the Bali area. Dyeing and screen printing business in Bali has increased the community effort space as well as the potential to pollute water resources, thus requiring guidance and controlled through licensing instruments as a unity of licensing system contained in The Act on Protection and Environmental Management (UUPPLH) ${ }^{5}$. To get clear river water in the city of Denpasar is not an easy job. Most of the river flows had been suspected to be

1 Silalahi, M.D. (1992). Hukum Lingkungan Dalam Sistem Penegakan Hukum Lingkungan Indonesia. Bandung: Alumni, p. 168.

2 Hardjasoemantri, K. (1991). Hukum Perlindungan Lingkungan Konservasi Sumber Daya Alam Hayati dan Ekosistemnya. Yogyakarta: Gadjah Mada University Press, p. 127.

3 Gea, A.A., and Wulandari, A.P.Y. (2005). Relasi dengan Dunia. Jakarta: PT. Elex Media Komputindo, p. 58-59.

4 Keraf, S. (2014). Etika Lingkungan Hidup. Bandung: PT. Sinar Grafika, p. 10.

5 Helmi. (2012). Hukum Perizinan Lingkungan Hidup. Jakarta: Sinar Grafika, p.77. 
contaminated with various types of waste, such as silk screen waste which can trigger river water pollution in Denpasar by the number of screen printing industries dumping waste directly into the river that can damage the river ecosystem and cause the river water to be colored. The area that became the choice of screen printing business in Denpasar City such as Pemogan, Padangsambian, and Pedungan village. These conditions occur to date, such as information Balipost dated October 1, 20176 which states Tukad River water in Badung Pemogan bubbles flying foam and bubbly suspected of industrial dyes or dyeing or laundry or household waste.

Presumption of pollution also occur in Bangli Regency against Lake Batur water so it is not worth consuming the surrounding community. ${ }^{7}$ This was as a result of the use of drugs from chemicals for agricultural activities around Lake Batur. The same thing happened in Tabanan regency, Lake Beratan water in Baturiti district based on laboratory test result in April 2017 allegedly started terermar by COD (Chemical Oxygen Demand) which had exceeded the environmental quality standard caused by the accumulation of chemical fertilizer substance produced by vegetable farming near the lake and leftover fuel boat. ${ }^{8}$ In Klungkung Regency, ${ }^{9}$ river water in Timuhun Village, Banjarangkan District was suspected to be contaminated with peanut waste from Nyanglan Village, so it is cloudy, smelly, and cannot be utilized by the community. Presumption of water pollution also occurred in Dusun Juntal, Tinga-Tinga Village, Gerokgak District, Buleleng Regency, due to Diasinon rice spray drugs so the river water smelled unpleasant. ${ }^{10}$ Meanwhile, in Gianyar regency, some springs were suspected to be contaminated with E-Coli bacteria because people dump livestock, garment livestock, and waste disposal of villas, hotels and restaurants into the river. ${ }^{11}$ If the water is polluted it will adversely affect the daily life of the community. ${ }^{12}$

\section{Legal Sanctions on The Act Number 32 of 2009 In Protecting Water Resources from Pollution}

Bali Province Regional Regulation Number 1 of 2017 on Protection and Environmental Management, regulates the protection of water resources in Article 11 paragraph (3) which stipulates the scope of environmental pollution control including pollution of surface water, sea water, air, the waste by hazardous and toxic materials, and solid waste. Furthermore, the Article 45 point b generally stated that every person conducting business and/or activity is obliged to maintain the sustainability of environmental

6 Bali Post. (2017). "Diduga Limbah, Sungai Dipenuhi Busa". Available online at: http://www.balipost.com/news/2017/09/15/21619 Accessed on October 2, 2017.

7 Bali Post. (2017). "Cegah Pencemaran Air, Petani Desa Buahan Mulai Terapkan Pertani". Available online at: http://www.balipost.com/news/2017/08/21/18875 Accessed on October 20, 2017

8 Nusa Bali. (2017). "Air Danau Beratan Tercemar", Available online at: http://www.nusabali.com/berita/8130/air-danau-beratan-tercemar Accessed on October 23, 2017,

9 Bali Post. (2017). Industri Kacang Cemari Sungai Desa Timuhun, Air Berubah Keruh dan Berbau Tak Sedap, http://www.balipost.com/news/2017/06/20/Industri-Kacan-Cemari-Sungai-Desa-Timuhun....html. Accessed on October 20, 2017.

10 Bali Post, accessed on November 3, 2017, Masih Berbau Diasinon, Warga Diminta Tidak Konsumsi Air Desa, http://www.balipost. com/news/2017/07/13/Masih-Berbau-Diasinon-Warga-Diminta-Tidak-KonsumsiAir-Desa, ....html.

11 Bali Tribun, accessed on October 23, 2017, Maraknya Pencemaran Lingkungan, DLH Gianyar Temuka Bakteri Ecoli di Air Beji, http://www. bali.tribunnews.com/2017/07/05/maraknya- pencemaranlingkungan,-DLH-gianyar-temukan-bakteri-ecoli-di-air-beji.

12 Erwin, M. (2011). Hukum Lingkungan Dalam Sistem Kebijaksanaan Pembangunan Lingkungan Hidup. Third edition. Bandung: PT. Refika Aditama, p. 37. 
functions ${ }^{13}$. In addition to the Bali Provincial Regulation Number 1 of 2017, the Provincial Government of Bali has also established Bali Provincial Regulation Number 11 of 2009 on Integrated River Basin Management.

Based on the consequences that can occur in environmental pollution including water resources, both direct and latent, the various efforts must be developed by the Government, the community, and the entrepreneur. Preventive efforts, among others, through the determination of environmental quality standards, Environmental Impact Analysis requirements, licensing and application of light administrative sanctions. The repressive efforts can be through application of sanctions from administrative law, civil law or criminal law ${ }^{14}$.

Administrative Law Sanctions, in the form of warning, government coercion, forced money, closure of business place, suspension of license to license revocation by the Government. Implementation of these sanctions is inherent to the Government, so it is done without the aid of the judiciary. Civil Law sanctions are compensation claims with or without the obligation to perform certain actions and payment of forced money (dwangsom). The legal basis of the lawsuit is Article 1365 Civil Code related to the alleged pollution of water resources by a person, legal entity, or by the Government. Sanction of Criminal Law namely criminal prosecution in the form of a principal penalty with or without additional criminal sanction.

Administrative Law Sanctions in the Act Number 32 of 2009 which is threatened to any act that violates the regulation in the field of environmental protection and management including water resources be regulated in Articles 76-82. Provisions of violations of this Administrative Law exist that identify narrowly in relation to compliance with environmental licenses. 15 This statement was not entirely true, since the environmental license is essentially part of the license requirements for operational licenses such as a business license of a lien. Meanwhile, the regulation concerning the application of civil law sanction in the form of indemnity is found in Article 87, Article 88, Article 90-92 of The Act Number 32 of 2009. While regarding sanction of Criminal Law regulated in Article 97-120 of The Act Number 32 of 2009, Chapter XV concerning Criminal Provision with criminal qualification.

Administrative sanctions and civil sanctions in The Act Number 32 of 2009 has been adopted in the enforcement of Regional Regulations, as in The Local Regulation of Bali Provincial Number 1 of 2017, The Local Regulation of Bali Provincial Number 11 of 2009, The Local Regulation of Badung Regency Number 7 of 2016 on Public Order and Public Order, The Local Regulation of Denpasar City Number 1 of 2015, The Local Regulation of Klungkung Regency Number 2 of 2014 on Public Order, and The Local Regulation of Karangasem Regency Number 4 of 2010 jo. The Local Regulation of Karangasem Regency Number 4 of 2013 on Public Order.

Administrative sanctions on local regulations in the form of written warnings generally initiate the action of dismantling, discharging or removal orders. The penalty sanctions are adjusted for proven losses. The duration of imprisonment varies from no more than

13 The explaination of the article states quite clearly, but the scope of the letters point e and $\mathrm{f}$, have no meaning when it is associated with the introductory its norm. This will certainly potentially multiinterpretation in its application.

14 Machmud, S. (2012). Penegakan Sanksi Lingkungan Indonesia, Yogyakarta: Graha Ilmu, p. 163.

15 Nagara, G. (2017). “Perkembangan Sanksi Administratif Dalam Penguatan Perlindungan Lingkungan Terkait Eksploitasi Sumber Daya Alam (Studi Kasus: Sektor Perkebunan, Pertambangan, dan Kehutanan)", Jurnal Hukum Lingkungan Indonesia, 3 (2): 19-47. 
3 (three) months to 6 (six) months according to the type of violation. Similarly, the penalty sanction ranging from Rp.1.000.000 (one million rupiah), Rp.10.000.000 (ten million rupiah), Rp.25.000.000 (twenty five million rupiah), and Rp.50.000.000 (five tens of millions of rupiah). It certainly does not conflict with the provisions of Article 238 paragraph (2) and (3) of the Act Number 23 of 2014 jo. Article 15 of the Act Number 12 of 2011 which stipulates local regulations may contain "a penalty imprisonment of a maximum on 6 (six) months or a fine of not more than Rp.50.000.000 (fifty million rupiahs).

Where the three forms of sanctions were compared, the Administrative Law sanctions was easiest and quick to apply to protect the water resources from pollution. Governments was authorized to, where necessary, without the necessity of the intermediary of the judges in advance to act significantly away by giving warnings or delaying the implementation of a license for alleged water pollution. This opens up the community's participation in the process of licensing, monitoring and participation in proposing policies to enforce administrative sanctions ${ }^{16}$.

The objectives of administrative sanctions were those that violate the provisions of laws and regulations, so in principle different from the provision of criminal sanctions and civil sanctions addressed to the person (the perpetrator). This was in line with the opinions of J. Dara Lynott and Ray Cullinane in his article entitled Administrative Sanction, which suggests: ${ }^{17}$

However, from a qualitative perspective, it was concluded that the administrative enforcement regimes could potentially be efficient for the following reasons:

a) The procedure is faster and less costly as compared to criminal proceedings, the results of which are uncertain.

b) The competent administrative authority can take a measure that is immediately applicable so that the environmental infringement can be tackled in the shortest delay, notwithstanding the possibility for the addressee to challenge such decision before a court.

c) The administrative enforcement regime offers a great variety of measures, including accessory measures that can be applied either before or concurrently to the sanction imposed; any such measures may have either an incentive effect or a coercive nature.

Administrative sanctions was also more preventive and easier and quicker to implement than Criminal or Civil sanctions. However, in the election of the applicability of the above sanctions both independently and collaboratively, it was necessary to adjust to the situation on the ground and on the basis of consideration of the normative, instrumental, and useful criteria.

\section{Conclusion}

The legal sanctions developed by The Act Number 32 of 2009 in protecting of water resources from pollution in the form of administrative law sanctions (Articles 76-82), civil law sanctions (Articles 87-92), as well as criminal law sanctions (Articles 97-120). In the local regulation in Bali Province, the three types of legal sanctions had been adopted. The measures against legal products on water resources at the central level was qualified

16 Akib, M. (2011). Penegakan Hukum Lingkungan Dalam Perspektif Holistik-Ekologis, Bandar Lampung: Universitas Lampung, p. 40.

17 Lynott, J.D., and Cullinane, R. (2010). “Administrative Sanctions”, Irish Planning and Environmental Law Journal, 17 (1). 
as crimes, on the other hand the legal products on water resources in the local area was qualified as violations.

Finally, based on various types of sanctions in The Act Number 32 of 2009, types of administrative law sanctions were more effectively implemented in protecting water resources from pollution. Application of the Administrative Law Sanctions was not through mediation of judges. Minister, Governor, Regent/Mayor in accordance with their authority to when necessary, without the necessity of judge intermediary in advance acting significantly by giving warning or delaying the implementation of an activity/business which was suspected to cause pollution to water resources. In addition, administrative sanctions were more preventive and easier and quicker to implement in providing protection against water resources, if be compared to sanctions in both Criminal and Civil Law.

\section{References}

Akib, M. (2011). Penegakan Hukum Lingkungan Dalam Perspektif Holistik-Ekologis, Bandar Lampung: Universitas Lampung.

Erwin, M. (2011). Hukum Lingkungan Dalam Sistem Kebijaksanaan Pembangunan Lingkungan Hidup. Third edition. Bandung: PT. Refika Aditama.

Gea, A.A., and Wulandari, A.P.Y. (2005). Relasi dengan Dunia. Jakarta: PT. Elex Media Komputindo.

Hardjasoemantri, K. (1991). Hukum Perlindungan Lingkungan Konservasi Sumber Daya Alam Hayati dan Ekosistemnya. Yogyakarta: Gadjah Mada University Press.

Helmi. (2012). Hukum Perizinan Lingkungan Hidup. Jakarta: Sinar Grafika.

Keraf, S. (2014). Etika Lingkungan Hidup. Bandung: PT. Sinar Grafika.

Lynott, J.D., and Cullinane, R. (2010). "Administrative Sanctions", Irish Planning and Environmental Law Journal, 17 (1).

Machmud, S. (2012). Penegakan Sanksi Lingkungan Indonesia, Yogyakarta: Graha Ilmu.

Nagara, G. (2017). “Perkembangan Sanksi Administratif Dalam Penguatan Perlindungan Lingkungan Terkait Eksploitasi Sumber Daya Alam (Studi Kasus: Sektor Perkebunan, Pertambangan, dan Kehutanan)", Jurnal Hukum Lingkungan Indonesia, 3 (2): 19-47.

Silalahi, M.D. (1992). Hukum Lingkungan Dalam Sistem Penegakan Hukum Lingkungan Indonesia. Bandung: Alumni

Other sources:

Bali Post, accessed on November 3, 2017, Masih Berbau Diasinon, Warga Diminta Tidak Konsumsi Air Desa, http://wwww.balipost.com/news/2017/07/13/Masih-Berbau-DiasinonWarga-Diminta-Tidak-Konsumsi-Air-Desa, ....html.

Bali Post. (2017). "Cegah Pencemaran Air, Petani Desa Buahan Mulai Terapkan Pertani". Available online at: http://www.balipost.com/news/2017/08/21/18875 Accessed on October 20, 2017

Bali Post. (2017). "Diduga Limbah, Sungai Dipenuhi Busa". Available online at: http://www.balipost.com/news/2017/09/15/21619 Accessed on October 2, 2017.

Bali Post. (2017). Industri Kacang Cemari Sungai Desa Timuhun, Air Berubah Keruh dan Berbau Tak Sedap, http://www.balipost.com/news/2017/06/20/Industri-Kacan-CemariSungai-Desa-Timuhun....html. Accessed on October 20, 2017. 
Bali Tribun, accessed on October 23, 2017, Maraknya Pencemaran Lingkungan, DLH Gianyar Temuka Bakteri Ecoli di Air Beji, http://www. bali.tribunnews.com/2017/07/05/ maraknya-pencemaran-lingkungan,-DLH-gianyar-temukan-bakteri-ecoli-di-air-beji.

Nusa Bali. (2017). "Air Danau Beratan Tercemar", Available online at: http://www.nusabali. com/berita/8130/air-danau-beratan-tercemar Accessed on October 23, 2017, 